\title{
Equalization of opportunities in the tertiary level of education of students with special needs in the Czech Republic - innovation programme of services at the University of Hradec Kralove
}

\author{
Kamila Ruzickova ${ }^{1 \mathrm{a}}$ \\ ${ }^{1}$ University of Hradec Králové, Hradec Kralove 500 03, Czech Republic
}

\begin{abstract}
The specialized text describes the standard rules of the equalization of opportunities at the tertiary level of the education of students with special needs in the Czech Republic. National standard recommendations for support services at Czech universities and colleges are presented in the first part of the article. The next part concentrates specifically on the innovative programme of services for students with special needs at the University of Hradec Kralove. The final part of the article provides the selected results of research study into the level of support services at the University of Hradec Kralove. Data were obtained from 52 respondents - kye workers for equalization of opportunities for students with special needs. A set of questionnaire was analysed using descriptive statistic. The first selected data demonstrate the status of readiness the innovated service system at the University of Hradec Kralove
\end{abstract}

Keywords: Equalization of opportunities; students with special needs; tertiary level of education.

\section{The current situation in the tertiary education of students with special needs in the Czech Republic}

In responding to the global agenda on providing Education for All, gaining access to learning, and successful participation in higher education institutions is becoming an ongoing priorities. Emphasis on equitable access has led to quality learning which contributes significantly to the development of national human resources, promotes social justice and cohesion as well as enhances personal development, [15,6,9]. Principle aspects on diversity, inclusion and equity have been identified in an OCED Report: equity of access or equality of opportunity; equity of terms of learning environment or equality of means;

\footnotetext{
${ }^{a}$ Corresponding author: author@e-mail.org
} 
equity of achievement and equity of in using the result of education or equality of application, [5].

The support of integrated forms of education in the Czech Republic started after 'Velvet Revolution' in 1989. Tertiary education is available in the Czech Republic almost exclusively in an integrated form. This implies a high degree of specific needs of the student with special needs and corresponding requirements to make education accessible by providing services which would equalize the study conditions. (The National plan of the Creation of Equal Opportunities for Persons with Disabilities for 2010-2014) So today we have more than twenty five years of experience and the system of support measures has been constantly evolving.

The system of support measures for children, pupils and students with special educational needs in pre-primary, primary and secondary degrees of education are sufficiently specifically defined in the Education Act (561/2004).

In contrast, the Czech Universities Act (111/1998) does accept 'the right for education of each individual', but the specific form of system support has not been implemented in it yet (the reason is a planned reform which has been, however, long-term delayed), [16]. In practice, however, the situation is not as negative as might result from the legislative situation. A temporary solution to the legislative deficit is the methodical instruction of the Ministry of Education on financing increased requirements on study.

Universities can apply for an annual subsidy if they meet the following conditions:

- to set up a specialized department which is able to guarantee (personally, technically and organizationally) providing services to satisfy the special needs of students;

- to demonstrate that they have taken organizational measures identical for the whole university or its part;

- to demonstrate that the departments are able to implement support measures in accordance with minimum quality standards set out in the methodical instruction.

To claim funding for students with special educational needs. (Currently valid rules for the financing of additional costs of studying students with special needs of The Ministry of Education and Sports, 2011).

At present, the conditions of equalization of opportunities for study at university in the Czech Republic are formally declared. However, the quality of services at specific universities is very diverse and claimable for students only to the extent to which the services are declared in the regulations of specific university. The long-awaited amendment of Universities Act is expected to solve this problem and achieve uniform conditions for all university students with special needs. (The update of Strategic Plan for the educational, scientific, research, development and innovation, artistic and other creative activities for higher education, 2012)

\section{Support measures at the University of Hradec Kralove}

Since 2001, the University of Hradec Králové (the UHK) has been developing efforts regarding widening access to education for students with disabilities. The first stage was equipping a special room for students with visual impairments. The equipment has been gradually extended by other aids and adaptations for other target groups,[13].

In 2008, 'Support Centre for Students with Special Needs Augustin' (the Augustin Centre) was founded. The centre provides consulting and support services to applicants and students with special needs. Support measures follow the Czech standard and offer students the following services: consulting; access to study materials; personal and academic assistance; interpreting and note-taking service, training of orientation in the environment; directorial measures (time compensation, access to environment, classroom equipment, etc.). 
The UHK is currently fully barrier-free $=$ accessible to students with special needs. Supportive measures at the UHK are implemented according to the Rector's Decree $(15 / 2013)$ and its Guideline. (The guidelines for organizing support for students with special needs, 2014) The support is available to the students through the coordinated cooperation of key employees and the services of the Augustin Centre. The key provider of services is the Augustin Centre (regular and external staff: special teachers, coordinators, assistants, interpreters and others). Each faculty established the management and control position of 'faculty coordinator'. Each workplace (institute/department) has a 'tutor of students with SN' (who coordinates cooperation of teachers with the Augustin Centre). Support measures at the UHK are provided by 8 permanent or external employees of the Augustin Centre, 6 faculty coordinators and 36 tutors of students with special needs. Furthermore, students with SN can benefit from other related services of the Counselling Centre of the UHK.

The major mechanisms also include a regular evaluation of the level of support measures which was initiated by the ESF project (reg. no. CZ.1.07/2.2.00/29.0004) entitled 'Improving and Expanding the Possibilities of Study at the UHK for students with special needs' was implemented (in the years 2012 - 2015). Thanks to the project, any student, who is entitled to an alternative form of documents, receives study materials in formats accessible for him/her. Training of teachers and other employees through e-learning programme is permanently available. Experiential and educational courses are provided for both teachers and students. Now we are in the situation after the completion of the first evaluation. The following section will present selected results of the evaluation research. The aim of this paper is to investigate current status of readiness the University staff to acceptance the innovated service system of support for students with $\mathrm{SN}$.

\section{Quantitative indicators of the support of students with special needs at the UHK}

To assess the level of support measures in the context of compliance to standards to which the UHK committed itself, qualitative and quantitative indicators were used. One of the qualitative indicators was internal evaluation conducted through the analysis of long-term targets of the university and comparison with the actual level of the support of students with special needs. As a complementary means, the technique of external evaluation was used. Specifically, it is an analysis of documents: the strategic plan, annual report and selected data from the research at the university departments (personal interviews with secretaries of departments).

In 2012 the Augustin Centre ensured support measures for equalization of conditions during the admission process to 17 applicants; 9 were admitted to study. During the year, 17 students with special needs used the services of the Augustin Centre, of which were 7 students with visual impairment, 5 with physical disabilities, 2 with hearing impairment and 3 with specific learning disorders. In 2013 the Augustin Centre ensured support measures during the admission process to 39 applicants; 17 started their studies. During 2013, 38 students with special needs used the services of the Centre. They were 7 students with visual impairment, 3 with physical disabilities, 5 with hearing impairment, also 17 students with specific learning disorders and 6 with chronic somatic disabilities. In 2014 the services were provided to 41 applicants with special needs; 5 of them started their studies. The services of the Centre were used by 7 students with visual impairment, 3 with hearing impairment, 5 with physical disabilities, 23 students with specific learning disorders and 7 with chronic somatic disabilities.

This list shows significant increase in the interest of students with special needs in study at the UHK and the quantity of provided services. Within the framework of all educational 
and awareness-raising events on the issue of inclusion and special needs of students with SN, more than 500 students without disabilities were supported in 2014; 44 teachers and other key workers successfully passed an e-learning educational course for the employees of the UHK (the course will remain accessible to new candidates).

\section{Status of readiness the University staff of acceptance the innovated service system of support for students with $\mathrm{SN}$ - research methodology}

To assess the current level of acceptance the new system of service for student with $\mathrm{SN}$ at the UHK, the method of questioning in the form of online inquiry for the key employees of the UHK was chosen. The data were processed by mathematical-statistical analysis by means of MS Excel and objectively interpreted. Selected items of questionnaires were used for the qualitative assessment - recording specific problematic situations and experiences.

The results of the inquiry are used to evaluate the degree of experience of the employees with applicants and students with SN in the study at the UHK. These were employees who were trained in the provision of special needs of students with $\mathrm{SN}$ and in the organization of these activities at the UHK. The research was conducted in the period from January to December 2014. The research group included 52 key workers of the UHK. The overwhelming majority of these employees had experience with dealing with students with $\mathrm{SN}$ and their education.

The questionnaire for the employees of the UHK consisted of 17 points; also here semiclosed questions prevailed. The questionnaire looked for the following areas of information: the level of experience of the employees of the UHK with teaching; the level of experience with teaching students with SN; the support measures most frequently used by the teachers of the UHK and views of key workers concerning the newly implemented system of providing support measures.

\section{Findings and discussion}

The demographic data of the respondents are presented in Table 1. The respondents are mostly equally represented by gender, working experience as well as hierarch of position. The research sample consisted of 52 employees of the UHK: 4 faculty coordinators, 17 tutors, 13 teachers, 15 support workers and others (Ph.D. student, coach, coordinator of interpreting service). The level of experience of the employees of the UHK with the communication/education of students with SN is as follows: $37 \%$ have experience with communication or education with more then 3 - 10 students with SN; $20 \%$ of respondents reported experience with more than 10 students with SN.

The results further show that, in personal communication with students with $\mathrm{SN}, 30$ respondents $(40 \%)$ did not report any problems, 11 respondents $(30 \%)$ faced less serious problems and $11(30 \%)$ had to deal with serious difficulties in communication and education. A surprising result is that the measure 'preparation of written materials for teaching' had not been used yet by any of the respondents.

Employees expressed a positive attitude to the need of the implementation of support measures, which the UHK committed itself to provide to students with SN at the University, and to the system of their organization. The vast majority of respondents $(92.30$ $\%$ ) fully accept the proposed system of ensuring the organization of support measures through the coordination of activities of key workers: tutor of the students - teacher - the Augustin Centre - faculty coordinator. The vast majority of respondents (98\%) also 
positively respond to the offer of support measures which the University committed itself to provide to students with SN during the study.

Table 1. The demographic data of the respondents

\begin{tabular}{|c|c|c|}
\hline Item & $\mathrm{f}$ & Percentages (\%) \\
\hline \multicolumn{3}{|l|}{ Gender } \\
\hline Male & 14 & 26.92 \\
\hline Female & 38 & 73.08 \\
\hline$\sum$ & 52 & 100.00 \\
\hline \multicolumn{3}{|c|}{ Working experience (only teachers, $n=29$ ) } \\
\hline $0-2$ years & 2 & 06.89 \\
\hline $3-5$ years & 3 & 10.34 \\
\hline $6-10$ years & 5 & 17.24 \\
\hline $11-15$ years & 4 & 13.80 \\
\hline $16-25$ years & 11 & 37.93 \\
\hline More years & 4 & 13.80 \\
\hline$\sum$ & 29 & 100.00 \\
\hline \multicolumn{3}{|l|}{ Key worker position } \\
\hline Faculty coordinator & 4 & 07.69 \\
\hline Tutor of students with SN & 17 & 32.69 \\
\hline Teacher (prof., ass. prof., lector) & 13 & 25.00 \\
\hline Support staff & 18 & 34.62 \\
\hline$\sum$ & 52 & 100.00 \\
\hline \multirow{2}{*}{\multicolumn{3}{|c|}{$\begin{array}{l}\text { Level of experiences with students with SN } \\
\text { (number of students) }\end{array}$}} \\
\hline & & \\
\hline 0 & 7 & 13.46 \\
\hline $1-2$ & 9 & 17.31 \\
\hline $3-10$ & 19 & 36.54 \\
\hline $11-20$ & 3 & 05.77 \\
\hline $21-50$ & 3 & 05.77 \\
\hline More & 4 & 07.69 \\
\hline Other replay & 7 & 13.46 \\
\hline$\Sigma$ & 52 & 100.00 \\
\hline
\end{tabular}

Based on these data it can be stated that most employees who became key workers in providing the service for students with $\mathrm{SN}$ have prior experience. Innovated system of measures are clearly rated most positively by university leaders and counselors. Teachers with a higher level of experience with students with SN have used more specific support strategies. Despite the high level of teaching experience of UHK employees, the level of experience of teaching students with SN is relatively low. This suggests the need for further education, especially of teaching staff of the UHK, so that they were ready to provide students with special needs with an adequate level of support. Concerning continuous education, the employees appeal for the development of quality specialized communication skills not only in basic social situations, but particularly focused on the needs of education 
and dealing with difficult situations. $75.00 \%$ key employees consider the support of teachers during teaching students with SN by Augustin centre as very good; $25 \%$ evaluated the support as good enough.

Table 2. The level of experience with teaching students with SN

\begin{tabular}{|c|c|c|}
\hline Item & $\mathrm{f}$ & Percentages $(\%)$ \\
\hline \multicolumn{3}{|l|}{ The frequency of using support measures by employees } \\
\hline Adaptation of the communication strategy & 14 & 25.50 \\
\hline Adjusting the organization of lectures & 3 & 05.86 \\
\hline Preparation of special study materials for lessons & 0 & 00.00 \\
\hline \multicolumn{3}{|l|}{ The provision of study materials in alternative formats } \\
\hline Individual tuition & 6 & 11.64 \\
\hline Without experience with support measures & 4 & 07.70 \\
\hline$\sum$ & 25 & 48.20 \\
\hline $\begin{array}{l}\text { Key workers views at the newly system of providing } \\
\text { support measures at the UHK }\end{array}$ & 52 & 100.00 \\
\hline \multicolumn{3}{|l|}{ Agree fully } \\
\hline Agree with reservations & 48 & 92.30 \\
\hline Disagrees & 4 & 07.70 \\
\hline$\sum$ & 0 & 00.00 \\
\hline $\begin{array}{l}\text { The employees' competence of communication and } \\
\text { education of students with SN (subjective assessment) }\end{array}$ & 52 & 100.00 \\
\hline \multicolumn{3}{|l|}{ Fully competent } \\
\hline \multicolumn{3}{|l|}{ Partly competent } \\
\hline \multicolumn{3}{|l|}{ With no competence } \\
\hline \multirow{4}{*}{$\Sigma$} & 32 & 61.54 \\
\hline & 17 & 32.69 \\
\hline & 3 & 05.77 \\
\hline & 52 & 100.00 \\
\hline
\end{tabular}

\section{Conclusion}

The analysis of support measures implemented into the system of education at the UHK enables to evaluate and further develop providing equal opportunities for studies of persons with special needs at the UHK. Based on the results of evaluation of the level of support and services, the Augustin Centre will draw up a draft for updating its activities and will pass it, together with other findings of the evaluation, to the supervising department of the UHK for consideration. The gathered data will be used for long-term monitoring of the development of quality of services.

Uniform instruments have not been developed yet in the Czech Republic for the assessment of universities focused on the area of evaluation and quality assurance in university counselling and providing support to students with special needs. So far, it is the responsibility of each university to respond to these needs by developing their own system. Last year also the University of Hradec Kralove began this journey of evaluation of the level of access to study for students with special needs. 


\section{References}

1. Act n. 561/2004., o předškolním, základním, středním, vyšším odborném a jiném vzdělávání. [Prepimary, primary, secondary, higher professional and other education]. Retrieved from: http://www.msmt.cz/dokumenty/skolsky-zakon, (2004).

2. Act n. 111/1998., o vysokých školách. [Universities Act]. Retrieved from: http:/www.msmt.cz/vzdelavani/vysoke-skolstvi/zakon-c-111-1998-sb-o-vysokychskolach-text-se-zapracovanymi, (1998)

3. Aktualizace Dlouhodobého záměru vzdělávací a vědecké, výzkumné, vývojové a inovační, umělecké a další tvưrčí činnosti pro oblast vysokých škol pro rok 2012, MŠMT [The update of Strategic Plan for the educational, scientific, research, development and innovation, artistic and other creative activities for higher education for 2012 from Ministry, The Ministry of Education and Sports]. Retrieved from: http://www.msmt.cz/file/16146, (2012).

4. Aktuálně platná pravidla MŠMT pro financování zvýšených nákladů na studium studentů se specifickými potřebami [Currently valid rules for the financing of additional costs of studying students with special needs of The Ministry of Education and Sports]. Retrieved from: http://www.msmt.cz/file/26979/, (2011).

5. Analýza současné situace studentů se specifickými nároky na vysokých školách Alevia 2010 [Analysis of the current situation of students with special needs at universities Alevia 2010]. Retrieved from: www.msmt.cz/vzdelavani/analyza-soucasne-situacestudentu-se-specifickymi-naroky-na, (2010)

6. Gorard, S., Quantitative Methods in Educational Research. London: Continuum, (2001).

7. Národní plán vytváření rovných příležitostí pro osoby se zdravotním postižením na období 2010-2014. [The National plan of the Creation of Equal Opportunities for Persons with Disabilities for 2010-2014]. [Retrieved from: http://www.vlada.cz/scripts/file.php?id=75865, (2014).

8. OECD Creating Effective Teaching and Learning Environments. Chapter 1, Diversity, Inclusion and Equity: Insights from Special Needs Provision. Retrieved from http://www.oecd.org/dataoecd/16/14/44978960.pdf, (2009).

9. Manisah, M., A. \& Zaleha, S., Perspektives on Readiness and Acceptance of Lectures in Supporting Students with Special Needs in Highr Education: A Case Study. Procedia Social and Behavioral Sciences, 7, 661 - 664, (2010).

10. Metodický pokyn k realizaci podpory uchazečů a studentů se SP na Univerzitě Hradec Králové, [The guidelines for organizing support for students with special needs]. Retrieved from: https://www.uhk.cz/cs-CZ/UHK/Uredni-deska/Uredni-deskauniversity.aspx. (2014).

11. Rektorský výnos 15/2013: Podpora uchazečů a studentů se specifickými potřebami na Univerzitě Hradec Králové. [The Rector's Decree 15/2013: Support for applicants and students with special needs at the Hradec Kralove University]. Retrieved from: https://www.uhk.cz/cs-CZ/UHK/Uredni-deska/Uredni-deska-university.aspx. (2013)

12. Růžičková, K. \& Skákalová, T. at al. (Eds.), „Seznamte se prosím“ - Metodický průvodce $\mathrm{k}$ organizaci podpory studentů se specifickými potřebami. ["Instructions Please" - The guidelines for organizing support for students with special needs]. Hradec Králové: Gaudeamus. ISBN 978-80-7435-381-9, (2014).

13. Růžičková, K. \& Kaliba M., Ověřování účinnosti podpory uchazečů a studentů se specifickými potřebami na Univerzitě Hradec Králové. (Eds.). [Verification of the effectiveness of aid applicants and students with special needs at the Hradec Kralove University]. In: Novosad, L. (Eds.). Rozvoj kompetencí vysokoškolských poradců napříč poradenským spektrem). Brno: AVŠP. ISBN 978-80-260-6483-1. (2014). 
14. Středisko podpory pro studenty se specifickými potřebami Augustin. Retrieved from: https://www.uhk.cz/cs-CZ/UHK/Centralni-pracoviste/Poradenske-centrum/Augustin.

15. Valentine, J. W., Principles and Practices for Effective Teacher Evaluation. Allyn \& Bacon, Boston, MA, (1992)

16. Zezulková, E. \& Krhutová, L., Studenti se speciálními potřebami na vysoké škole. [Students with special needs at the Universities] Ostrava: Ostravská univerzita v Ostravě. ISBN: 978-80-7368-450-1, (2008). 